\title{
KORELASI ANTARA KEBIASAAN MEMBACA DENGAN KEMAMPUAN MEMBACA PEMAHAMAN SISWA KELAS XI IPA SMAN 1 AMBUNTEN
}

\author{
Drs. Sauturrasik \\ Pengajar SMANegeri 1 Ambunten \\ joni.santoso19@yahoo.co.id
}

\begin{abstract}
ABSTRAK
Sebagian besar soal-soal Ujian Akhir Sekolah menuntut pemahaman siswa dalam mencari dan menentukan pikiran pokok, kalimat utama, membaca grafik, alur/plot, amanat, setting, dan sebagainya. Tanpa kemampuan membaca pemahaman yang tinggi, mustahil siswa dapat menjawab soal-soal tersebut. Di sinilah peran penting membaca pemahaman untuk menentukan jawaban yang benar. Belum lagi dengan adanya standar nilai kelulusan, hal ini memicu guru bahasa Indonesia khususnya untuk dapat mencapai target nilai tersebut. Rumusan masalah dalam penelitian ini adalah Adakah korelasi antara kebiasaan membaca dengan kemampuan membaca pemahaman siswa kelas XI IPA SMAN 1 Ambunten ? Sedangkan tujuannya adalah untuk mengetahui seberapa besar korelasi antara kebiasaan membaca dengan kemampuan membaca pemahaman siswa kelas XI IPA SMAN 1 Ambunten.

Metode yang digunakan dalam penelitian ini adalah Metode Analisis Korelasional. Populasi siswa kelas XI IPA SMAN 1 Ambunten tahun ajaran 2014-2015 terdiri dari tiga kelas, dengan jumlah siswa 102 orang. Adapun sampel yang akan diteliti sejumlah 50 orang, Pengambilan sampel dilakukan dengan teknik random sampling (acak). Random ini dilakukan dengan cara pengundian.

Berdasarkan Hasil penelitian statistik menunjukkan bahwa nilai $r$ hitung adalah 0,754 sedangkan $r$ tabel adalah 0,279 dengan batas signifikasi 5\%. Artinya bahwa nilai $r$ hitung lebih besar daripada nilai $r$ tabel, yakni 0,754> 0,279.Dengan demikian dapat disimpulkan berdasarkan hipotesis yang diajukan bahwa $H_{0}$ ditolak pada taraf signifikasi 5\%. Sedangkan hipotesis alternatif $\left(H_{1}\right)$ diterima, yang berarti terdapat korelasi yang positif antara kebiasaan membaca dengan kemampuan membaca pemahaman. Kriteria tingkat korelasi di atas, di mana nilai $r$ hitung adalah 0,754 berarti berada pada rentang nilai di antara 0,600 sampai dengan 0,800, maka dapat dikatakan bahwa nilai-nilai kebiasaan membaca dengan kemampuan membaca pemahaman siswa kelas XI IPA SMAN 1 Ambunten mempunyai tingkat korelasi cukup.
\end{abstract}

Kata Kunci : Kebiasaan Membaca, Kemampuan Membaca Pemahaman, Penelitian Tindakan Kelas (PTK).

\section{PENDAHULUAN}

Sejalan dengan perkembangan ilmu pengetahuan dan teknologi yang semakin pesat, terutama dalam teknologi percetakan maka semakin banyak informasi yang tersimpan di dalam buku. Pada semua jenjang pendidikan, kemampuan membaca menjadi skala prioritas yang harus dikuasai siswa. Dengan membaca siswa akan memperoleh berbagai informasi yang sebelumnya belum pernah didapatkan. Semakin banyak membaca semakin banyak pula informasi yang diperoleh. Oleh karena itu, membaca merupakan jendela dunia, siapa pun yang membuka jendela tersebut dapat melihat dan mengetahui segala sesuatu yang terjadi. Baik peristiwa yang terjadi pada masa lampau, sekarang, bahkan yang akan datang.

Banyak manfaat yang diperoleh dari kegiatan membaca. Oleh karena itu, sepantasnyalah siswa harus melakukannya atas dasar kebutuhan, bukan karena suatu paksaan. Jika siswa 
membaca atas dasar kebutuhan, maka ia akan mendapatkan segala informasi yang ia inginkan. Namun sebaliknya, jika siswa membaca atas dasar paksaan, maka informasi yang ia peroleh tidak akan maksimal.

Membaca merupakan kemampuan yang kompleks. Membaca bukanlah kegiatan memandangi lambang-lambang yang tertulis semata. Bermacam-macam kemampuan dikerahkan oleh seorang pembaca, agar dia mampu memahami materi yang dibacanya. Pembaca berupaya agar lambang-lambang yang dilihatnya itu menjadi lambang-lambang yang bermakna baginya.

Kegiatan membaca juga merupakan aktivitas berbahasa yang bersifat aktif reseptif. Dikatakan aktif, karena di dalam kegiatan membaca sesungguhnya terjadi interaksi antara pembaca dan penulisnya, dan dikatakan reseptif, karena si pembaca bertindak selaku penerima pesan dalam suatu korelasi komunikasi antara penulis dan pembaca yang bersifat langsung.

Bagi siswa, membaca tidak hanya berperan dalam menguasai bidang studi yang dipelajarinya saja. Namun membaca juga berperan dalam mengetahui berbagai macam kemajuan ilmu pengetahuan dan teknologi yang terus berkembang. Melalui membaca, kemajuan ilmu pengetahuan dan teknologi dapat diketahui dan dipahami sebelum dapat diaplikasikan.

Henry Guntur Tarigan berpendapat bahwa "Membaca adalah suatu proses yang dilakukan serta dipergunakan oleh pembaca untuk memperoleh pesan yang hendak disampaikan oleh penulis melalui media kata-kata atau bahasa tulis sedangkan pendapat DP Tampubolon, "Membaca merupakan satu dari empat kemampuan bahasa pokok, dan merupakan satu bagian atau komponen dari komunikasi tulisan.

Adapun kemampuan bahasa pokok atau keterampilan berbahasa dalam kurikulum di sekolah mencakup empat segi, yaitu : a. Keterampilan

menyimak/mendengarkan (Listening Skills)

b. Keterampilan berbicara (Speaking Skills)

c. Keterampilan membaca (Reading Skills)

d. Keterampilan Menulis (Writing Skills) Empat keterampilan berbahasa tersebut memiliki keterkaitan yang sangat erat satu sama lain, dan saling berkorelasi. Seorang bayi pada tahap awal, ia hanya dapat mendengar, dan menyimak apa yang di katakan orang di sekitarnya. Kemudian karena seringnya mendengar dan menyimak secara berangsur ia akan menirukan suara atau kata-kata yang didengarnya dengan belajar berbicara. Setelah memasuki usia sekolah, ia akan belajar membaca mulai dari mengenal huruf sampai merangkai huruf-huruf tersebut menjadi sebuah kata bahkan menjadi sebuah kalimat. Kemudian ia akan mulai belajar menulis huruf, kata, dan kalimat.

Keterampilan berbahasa berkorelasi dengan proses-proses berpikir yang mendasari bahasa. sehingga ada sebuah ungkapan, "bahasa seseorang mencerminkan pikirannya". Semakin terampil seseorang berbahasa, semakin cerah dan jelas jalan pikirannya.

Kegiatan membaca perlu dibiasakan sejak dini, yakni mulai dari anak mengenal huruf. Jadikanlah kegiatan membaca sebagai suatu kebutuhan dan menjadi hal yang menyenangkan bagi siswa. Membaca dapat dilakukan di mana saja dan kapan saja asalkan ada keinginan, semangat, dan motivasi. Jika hal ini terwujud, diharapkan membaca dapat menjadi bagian dari kehidupan yang tidak dapat dipisahkan seperti sebuah slogan yang mengatakan "tiada hari tanpa membaca".

Tentunya ini memerlukan ketekunan dan latihan yang berkesinambungan untuk melatih kebiasaan membaca agar kemampuan membaca, khususnya membaca pemahaman dapat 
dicapai. Kemampuan membaca ialah kecepatan membaca dan pemahaman isi secara keseluruhan.

Kenyataan menunjukkan soal-soal Ujian Akhir Sekolah (UAS) sebagian besar menuntut pemahaman siswa dalam mencari dan menentukan pikiran pokok, kalimat utama, membaca grafik, alur/plot, amanat, setting, dan sebagainya. Tanpa kemampuan membaca pemahaman yang tinggi, mustahil siswa dapat menjawab soal-soal tersebut. Di sinilah peran penting membaca pemahaman untuk menentukan jawaban yang benar. Belum lagi dengan adanya standar nilai kelulusan, hal ini memicu guru bahasa Indonesia khususnya untuk dapat mencapai target nilai tersebut.

Inilah yang membuat penulis tertarik untuk mengadakan penelitian guna mengetahui bagaimana kebiasaan membaca dan pemahaman siswa di Sekolah Menengah Atas. Penulis akan menuangkannya dalam skripsi dengan judul "Korelasi Antara Kebiasaan Membaca dengan Kemampuan Membaca Pemahaman Siswa Kelas XI IPA SMAN 1 Ambunten".

\section{METODE PENELITIAN}

\section{a. Jenis Penelitian}

Metode yang digunakan dalam penelitian ini adalah metode Analisis Korelasional.

\section{b. Variabel Penelitian}

Dalam penelitian ini ada dua variabel yang penulis gunakan, yaitu :

1. Variabel Bebas

Sebagai variabel bebasnya adalah kebiasaan membaca yang dilambangkan dengan huruf $\mathrm{X}$.

2. Variabel Terikat

Sebagai variabel terikatnya adalah kemampuan membaca pemahaman yang dilambangkan dengan huruf Y.

\section{c. Teknik Pengumpulan Data}

Dalam pengumpulan data, penulis mengumpulkan data dari dua sumber yakni data nilai angket kebiasaan membaca dari hasil pengisian angket, dan nilai kemampuan membaca pemahaman dari hasil tes kemampuan membaca pemahaman.

Penulis terlebih dahulu membagikan angket/kuesioner tentang kebiasaan membaca yang berjumlah 20 pertanyaan kebiasaan membaca yang berbentuk pilihan ganda dengan pilihan A, B, C, D, atau E. Instrumen angket kebiasaan membaca digunakan nilai/skor antara 1 sampai dengan 5 . Skor 1 untuk jawaban E, skor 2 untuk jawaban D, skor 3 untuk jawaban $\mathrm{C}$, skor 4 untuk jawaban $\mathrm{B}$, dan skor 5 untuk jawaban A. Jadi masing-masing pilihan jawaban itu dimaksudkan untuk melambangkan perbedaan kadar atau kualitas kebiasaan membaca yang dimiliki siswa secara tafsiran kuantitatif.

Kemudian melakukan tes kemampuan membaca pemahaman siswa dengan memberikan soal isian singkat dengan jumlah soal sepuluh. Dengan kriteria penilaian setiap jawaban yang benar diberi nilai/skor sepuluh.

\section{d. Instrumen Penelitian}

Instrumen yang digunakan untuk memperoleh data dalam penelitian ini adalah tes, dan non tes. Tes dilakukan dengan memberikan soal-soal isian yang berjumlah 10. Sedangkan untuk instrumen non tes dengan memberikan angket/kuesioner tentang data kebiasaan membaca siswa. Angket/Kuesioner yang diberikan berbentuk pilihan ganda, sebuah daftar pertanyaan di mana responden tinggal memilih salah satu jawaban yang sesuai dengan kebiasaan membacanya masing-masing dengan memberi tanda silang (X) pada jawaban yang dipilih (tes dan angket terlampir).

\section{e. Teknik Analisis Data}

Prosedur yang dilaksanakan dalam menganalisis data sebagai berikut : 
1. Pemeriksaan dan pemberian nilai pada setiap angket dan hasil tes.

2. Untuk angket/kuesioner kebiasaan membaca diberi nilai antara 1 sampai dengan 5 .

3. Hasil tes kemampuan membaca pemahaman, setiap jawaban yang benar diberi nilai sepuluh, jawaban yang mendekati benar diberi nilai 5 , dan yang salah diberi nilai nol.

4. Menghitung hasil nilai angket/ kuesioner kebiasaan membaca siswa yang dijadikan sampel dengan simbol $\mathrm{X}, \mathrm{X}^{2}$, dan $\mathrm{XY}$.

5. Menghitung hasil nilai kemampuan membaca pemahaman siswa dengan menggunakan simbol $\mathrm{Y}$, $\mathrm{Y}^{2}$, dan XY.

6. Menjumlahkan hasil perkalian antara kebiasaan membaca dengan kemampuan membaca pemahaman.

7. Menghubungkan kedua nilai tersebut dengan menggunakan rumus korelasi product moment, untuk mengetahui ada atau tidak adanya hubungan pada kedua variabel tersebut.
Adapun rumus korelasi product moment yang digunakan penulis adalah sebagai berikut :

$$
r_{x y}=\frac{N \cdot \sum x y-\left(\sum x\right)\left(\sum y\right)}{\sqrt{\left\{N \cdot \sum x^{2}-\left(\sum x\right)^{2}\right\}\left\{N \cdot \sum y^{2}-\left(\sum y\right)^{2}\right\}}}
$$

Keterangan :

$r_{\mathrm{xy}}=$ Korelasi antara variabel $\mathrm{X}$ dan Y

$\mathrm{X}=$ Hasil kebiasaan membaca siswa kelas XI IPA SMAN 1 Ambunten

$\mathrm{Y}=$ Hasil kemampuan membaca pemahaman siswa kelas XI IPA SMAN 1 Ambunten

$X Y=$ Hasil kali dua variabel antara $X$ dan Y

$\mathrm{N}$ = Jumlah sampel penelitian

\section{PEMBAHASAN}

Berikut ini adalah data yang dikumpulkan penulis dari dua sumber, yakni data nilai tes kebiasaan membaca dan nilai tes kemampuan membaca pemahaman.

Tabel 1. Hasil Tes Kebiasaan Membaca

\begin{tabular}{cllllllllllllll}
\hline No & $\begin{array}{l}\text { Nama } \\
\text { Siswa }\end{array}$ & Nilai & No & $\begin{array}{l}\text { Nama } \\
\text { Siswa }\end{array}$ & Nilai & No & $\begin{array}{l}\text { Nama } \\
\text { Siswa }\end{array}$ & Nilai & No & $\begin{array}{l}\text { Nama } \\
\text { Siswa }\end{array}$ & Nilai & No & $\begin{array}{l}\text { Nama } \\
\text { Siswa }\end{array}$ & Nilai \\
\hline 1 & AR & 80 & 11 & KU & 76 & 21 & RS & 77 & 31 & SD & 76 & 41 & ARF & 79 \\
\hline 2 & AN & 79 & 12 & KJ & 77 & 22 & RY & 79 & 32 & SH & 77 & 42 & ARM & 80 \\
\hline 3 & AF & 76 & 13 & KR & 80 & 23 & RE & 79 & 33 & SAR & 82 & 43 & ARN & 76 \\
\hline 4 & BQ & 79 & 14 & LO & 76 & 24 & RP & 75 & 34 & UA & 80 & 44 & AMH & 75 \\
\hline 5 & CN & 79 & 15 & MB & 80 & 25 & R & 77 & 35 & ZR & 76 & 45 & ATK & 75 \\
\hline 6 & D & 79 & 16 & MH & 78 & 26 & RD & 78 & 36 & HM & 80 & 46 & AFD & 77 \\
\hline 7 & E & 75 & 17 & NF & 79 & 27 & R & 78 & 37 & AY & 80 & 47 & BR & 75 \\
\hline 8 & FR & 80 & 18 & NH & 79 & 28 & SA & 75 & 38 & AW & 77 & 48 & BTD & 75 \\
\hline 9 & GU & 77 & 19 & NT & 78 & 29 & SM & 77 & 39 & ARS & 76 & 49 & ES & 80 \\
\hline 10 & H & 80 & 20 & NH & 78 & 30 & SN & 80 & 40 & AFS & 77 & 50 & FS & 80 \\
\hline
\end{tabular}

Berdasarkan hasil di atas dapat dilihat bahwa dari 50 siswa yang mengikuti tes kebiasaan membaca terdapat 7 orang yang mendapat nilai 75 , 7 orang yang mendapat nilai 76,9 orang yang mendapat nilai 77,5 orang yang mendapat nilai 78,9 orang yang mendapat nilai 79,12 orang yang mendapat nilai 80,1 orang yang mendapat nilai 82. Dari hasil tersebut dapat diketahui nilai rata-rata sebesar 77,86 . 
Tabel 2. Hasil Tes Kemampuan Membaca Pemahaman

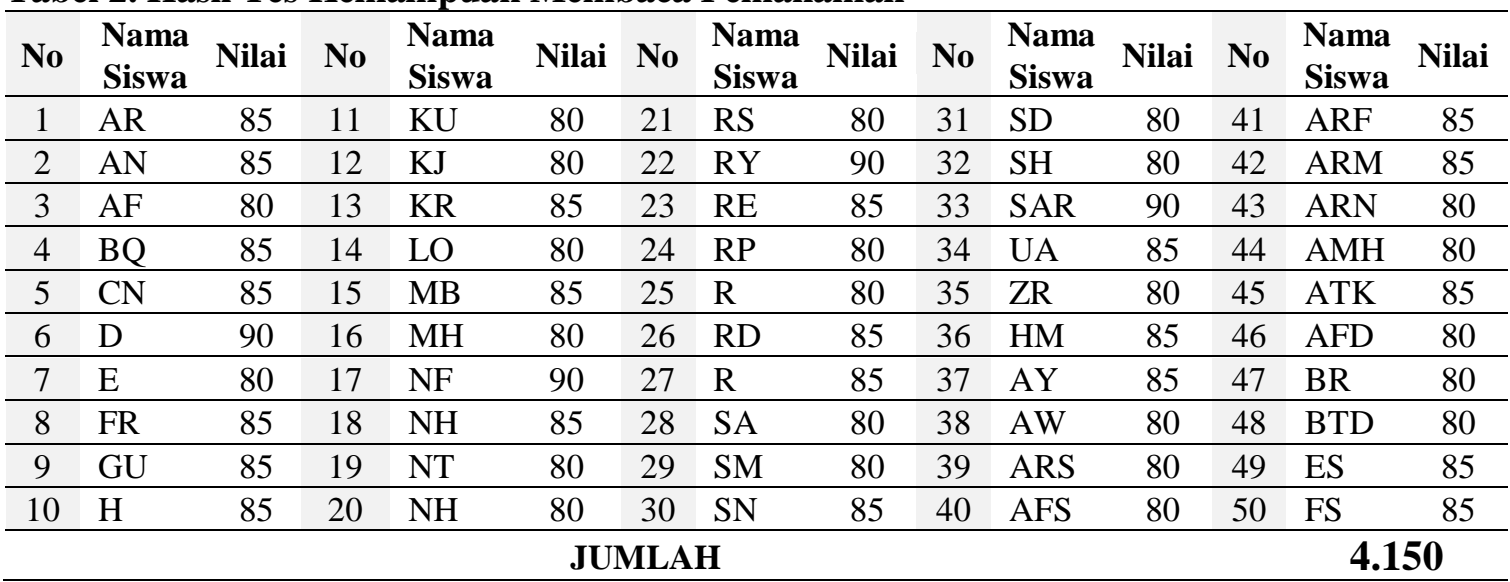

Berdasarkan hasil di atas dapat dilihat bahwa dari 50 siswa yang mengikuti tes kemampuan membaca pemahaman terdapat 24 orang yang mendapat nilai 80,22 orang yang mendapat nilai 85,4 orang yang mendapat nilai 90. Dari hasil tersebut dapat diketahui nilai rata-rata sebesar 83,00 .

\section{a. Deskripsi Data}

Setelah Penulis memperoleh data sampel penelitian dalam hal kebiasaan membaca dan membaca pemahaman siswa kelas XI IPA SMAN 1 Ambunten, Penulis dapat mengetahui rata-rata tingkat kebiasaan membaca siswa tergolong tinggi, dengan rata-rata skor 77,86. Begitu pula dengan data kemampuan membaca pemahaman siswa tergolong tinggi dengan rata-rata skor 83,00.

\section{b. Analisis Data}

Data yang telah dikumpulkan kemudian Penulis hitung dengan menggunakan rumus korelasi product moment, yakni :

$$
\mathrm{r}_{x y}=\frac{N \sum x y-\left(\sum x\right)\left(\sum y\right)}{\sqrt{\left\{N \sum x^{2}-\left(\sum x\right)^{2}\right\}\left\{N \sum y^{2}-\left(\sum y\right)^{2}\right\}}}
$$

Diketahui :

$\begin{array}{rlr}\mathrm{N} & = & 50 \\ \sum \mathrm{X} & = & 3.893 \\ \sum \mathrm{Y}= & 4.150 \\ \sum \mathrm{X}^{2}= & 303.281 \\ \sum \mathrm{Y}^{2}= & 344.950 \\ \mathrm{XY}= & 323.340 \\ (\mathrm{X})^{2}= & 15.155 .449 \\ (\mathrm{Y})^{2} & =17.222 .500\end{array}$

$$
\begin{aligned}
r_{x y} & =\frac{N \sum x y-\left(\sum x\right)\left(\sum y\right)}{\sqrt{\left\{N \sum x^{2}-\left(\sum x\right)^{2}\right\}\left\{N \sum y^{2}-\left(\sum y\right)^{2}\right\}}} \\
r_{x y} & =\frac{50 \times 323.340-(3.893)(4.150)}{\sqrt{\{(50 \times 303.281)-(15.155 .449)\}\{(50 \times 344.950)-(17.222 .500)\}}} \\
r_{x y} & =\frac{16.167 .000-16.155 .950}{\sqrt{(15.164 .050-15.155 .449)(17.247 .500-17.222 .500)}} \\
& =\frac{11.050}{\sqrt{8.601 \times 25.000}} \\
& =\frac{11.050}{\sqrt{215.025 .000}} \\
& =\frac{11.050}{14.663,73}=0,754(r \text { hitung })
\end{aligned}
$$


Dari hasil penelitian statistik di atas, diketahui bahwa nilai $r$ hitung adalah 0,754 sedangkan $r$ tabel adalah 0,279 dengan batas signifikasi 5\%. Artinya bahwa nilai $r$ hitung lebih besar daripada nilai $r$ tabel, yakni0,754>0,279.

Dengan demikian dapat disimpulkan berdasarkan hipotesis yang diajukan bahwa $\mathrm{H}_{0}$ ditolak pada taraf signifikasi 5\%. Sedangkan hipotesis alternatif $\left(\mathrm{H}_{1}\right)$ diterima, yang berarti terdapat korelasi yang positif antara kebiasaan membaca dengan kemampuan membaca pemahaman.

Untuk menyatakan dan menentukan tingkat korelasi antara kebiasaan membaca dan kemampuan membaca pemahaman. Penulis menggunakan kriteria rentang nilai korelasi koefisien yang Penulis kutip dari buku acuan Suharsimi Arikunto. Adapun kriterianya sebagai berikut :

$$
\begin{array}{ll}
0,800 \text { s.d } 1,000 & =\text { Tinggi } \\
0,600 \text { s.d } 0,800 & =\text { Cukup } \\
0,400 \text { s.d } 0,600 & =\text { Agak rendah } \\
0,200 \text { s.d } 0,400 & =\text { Rendah } \\
0,000 \text { s.d } 0,200 & =\text { Sangat rendah }
\end{array}
$$

(tidak ada korelasi)

Berdasarkan kriteria tingkat korelasi di atas, di mana nilai $r$ hitung adalah 0,754 berarti berada pada rentang nilai di antara 0,600 sampai dengan 0,800 , maka dapat dikatakan bahwa nilai-nilai kebiasaan membaca dengan kemampuan membaca pemahaman siswa kelas XI IPA SMAN 1 Ambunten mempunyai tingkat korelasi cukup.

\section{c. Interpretasi Data}

Dari hasil pengumpulan dan pengelolaan data, dapat diberikan interpretasi terhadap kebiasaan membaca dan kemampuan membaca pemahaman. Untuk memberikan interpretasi terhadap data, penulis menggunakan acuan nilai sebagai berikut:

Untuk nilai 0 s.d $60 \quad$ rendah Untuk nilai 61 s.d 75 sedang
Untuk nilai 76 s.d 100 tinggi

Untuk kebiasaan membaca, pada umumnya siswa memiliki tingkat kebiasaan membaca tinggi. Hal ini terbukti dari 50 siswa hanya terdapat 7 orang yang memiliki kebiasaan membaca tingkat sedang dan 43 orang memiliki tingkat kebiasaan yang tinggi. Artinya hanya $14 \%$ yang memiliki kebiasaan membaca tingkat sedang dan $86 \%$ memiliki kebiasaan membaca tingkat tinggi.

Demikian pula kemampuan membaca pemahaman, semua siswa memiliki kemampuan membaca pemahaman tingkat tinggi. Ini terbukti dari 50 siswa memiliki kemampuan membaca pemahaman tingkat tinggi. Artinya $100 \%$ siswa memiliki kemampuan membaca pemahaman tingkat tinggi.

\section{d. Usaha Mengembangkan Minat dan Kebiasaan Membaca}

Banyak usaha-usaha yang dapat dilakukan untuk mengembangkan minat dan kebiasaan membaca. Namun usaha-usaha itu memiliki sasaran yang berbeda. Bagi anak-anak yang belum dapat membaca, bertujuan utama untuk menumbuhkan minat membaca, yang sendirinya juga untuk mencapai kesiapan membaca. Akan tetapi, bagi anak-anak yang sudah dapat membaca, usaha-usaha itu mempunyai tujuan bukan hanya menumbuhkan, melainkan juga mengembangkan minat dan kebiasaan membaca.

Adapun usaha-usaha yang dapat dilakukan adalah sebagai berikut:

1) Pengaruh dan Peranan Orang tua

Komisi Plowden (1964) mengadakan survei nasional atas Sekolah-sekolah Dasar menyimpulkan bahwa faktor utama yang mempengaruhi kemajuan anak di sekolah adalah tingkat perhatian orang tua pada anak di rumah.

Begitu pula Komisi Bullock (1975) menyimpulkan 
bahwa peranan orang tua sangat menentukan dalam pendidikan anak, terutama pada tingkat prasekolah dan SD, khususnya dalam membaca dan perkembangan bahasa. Pengaruh dan peranan orang tua dapat dilakukan dengan:

a) Mendorong perkembangan bahasa anak.

b) Menjadi teladan dalam membaca.

c) Membaca dan bercerita.

d) Bermain dengan bacaan dan tulisan.

e) Memanfaatkan sarana-sarana lingkungan

Mendorong perkembangan bahasa anak dapat dilakukan terutama melalui percakapan-percakapan dengan anak. Cara mendorong perkembangan bahasa anak yaitu melalui peniruan, penyempurnaan, pengomentaran, dan responsi dorongan. Orang tua harus menjadi teladan bukan hanya dalam kehidupan keluarga dan masyarakat umumnya, tetapi juga dalam membaca.

Bercerita kepada anak memainkan peranan penting bukan saja dalam menumbuhkan minat dan kebiasaan membaca, tetapi juga dalam mengembangkan bahasa dan pikiran anak. Bermain-main dengan bacaan dan tulisan menumbuhkan minat dan kebiasaan membaca dan menulis dalam diri anak-anak.

Selain dari kegiatan-kegiatan di rumah dengan memanfaatkan sarana-sarana yang ada, orang tua juga perlu memanfaatkan berbagai sarana yang terdapat dalam lingkungan seperti toko buku, perpustakaan, kantor pos, televisi (TV), plaza, dan toko swalayan, dan lain-lain.

2) Membaca Dini

Membaca dini ialah membaca yang diajarkan secara terprogram (secara formal) kepada anak prasekolah.
DP. Tampubolon mengemukakan ada empat keuntungan mengajar anak membaca dini dilihat dari segi proses belajar mengajar:

a) Belajar membaca dini memenuhi rasa ingin tahu anak.

b) Situasi akrab dan informal di rumah dan di kelompok bermain (KB) atau taman kanak-kanak (TK) merupakan faktor yang kondusif bagi anak untuk belajar.

c) Anak-anak yang berusia dini pada umumnya perasa dan mudah terkesan, serta dapat diatur.

d) Anak-anak yang berusia dini dapat mempelajari sesuatu dengan mudah dan cepat.

Bertitik tolak dari pengertian bahwa membaca adalah kegiatan fisik dan mental untuk menemukan makna dari tulisan, dan membaca dini merupakan usaha mempersiapkan anak memasuki pendidikan dasar, DP. Tampubolon menyebutkan lima prinsip pokok membaca dini, yaitu:

a) Materi bacaan harus terdiri dari kata-kata, frase-frase, dan kalimat-kalimat. Ini berarti bahwa bacaan itu harus mempunyai makna yang dapat dipahami oleh anak.

b) Membaca terutama didasarkan pada kemampuan memahami bahasa lisan, dan bukan pada kemampuan berbicara.

c) Mengajarkan membaca bukan mengajarkan aspek-aspek kebahasaan seperti tata bahasa, kosa kata, dan lain-lain, dan bukan mengajarkan logika atau cara berpikir (walaupun membaca tidak terlepas dari proses berpikir). Bahan-bahan pelajaran membaca dini haruslah yang berada dalam ruang lingkup kemampuan bahasa dan berpikir anak. 
d) Membaca tidak harus bergantung pada pengajaran menulis. Ini berarti bahwa anak dapat diajar membaca, walaupun dia belum dapat menulis.

e) Pengajaran membaca harus menyenangkan bagi anak.

Dari penjelasan di atas kiranya dapat dilihat bahwa pengajaran membaca adalah bersifat individual. Program dan metode harus disesuaikan dengan perkembangan setiap anak. Dengan demikian, pada dasarnya orang tua atau guru KB atau TK dapat juga menyusun dan mengembangkan program (bahan-bahan pelajaran) nya sendiri dan juga metode mengajar sesuai dengan perkembangan anak atau anak-anak yang bersangkutan.

\section{KESIMPULAN DAN SARAN}

\section{a. Kesimpulan}

1. Berdasarkan hasil penelitian, diketahui nilai $r$ hitung adalah 0,754 sedangkan $r$ tabel adalah 0,279 pada taraf signifikasi 5\%. Dengan demikian hipotesis nol $\left(\mathrm{H}_{0}\right)$ dinyatakan ditolak, sedangkan hipotesis penelitian $\left(\mathrm{H}_{1}\right)$ dinyatakan diterima, artinya bahwa terdapat korelasi yang positif antara kebiasaan membaca dengan kemampuan membaca.

2. Kebiasaan membaca siswa kelas XI IPA SMAN 1 Ambunten memiliki rata-rata yang cukup tinggi.

3. Kemampuan membaca pemahamannya juga dapat dikatakan mencapai pada taraf rata-rata yang cukup tinggi.

\section{b. Saran}

1. Hendaknya siswa memiliki kebiasaan membaca yang tinggi, agar kemampuan membaca pemahaman dapat dicapai.

2. Hendaknya guru dapat meningkatkan kebiasaan membaca siswa dengan menambah jam wajib kunjung ke perpustakaan.
3. Hendaknya pihak sekolah mendukung usaha tersebut dengan memperhatikan fasilitas yang dapat menunjang, seperti menambah jumlah koleksi buku di perpustakaan. Hal ini penting dilakukan agar dapat memicu semangat dan motivasi siswa untuk membaca.

4. Hendaknya orang tua dapat memberikan contoh kepada anak dalam hal kebiasaan membaca agar dapat membentuk budaya baca.

\section{DAFTAR PUSTAKA}

Akhmad, S.H. 1996. Membaca 2. Jakarta: Cipta Karya.

Arikunto, Surhasimi. 1997. Prosedur Penelitian Suatu Pendekatan. Jakarta: Rineka Cipta.

Burhan, Jazir. 1971. Problema Bahasa dan Pengajaran Bahasa Indonesia. Bandung: GanatoNV.

Depdikbud. 1995. Kamus Besar Bahasa Indonesia. Jakarta: Balai Pustaka.

Harimurti Kridalaksana. 1984. Kamus Linguistik. Jakarta: PT. Gramedia.

Heryanto, Yusuf. 2002. Pengantar Linguistik. STKIP Muhammadiyah Bogor.

Keraf, Gorys. 1993. Komposisi. Cetakan $X I$. Nusa Indah. Ende-Flores.

Mulyati, Yet. 1997, Membaca. Jakarta: Cipta Karya.

Nurhadi. 1989. Bagaimana Meningkatkan Kemampuan Membaca. Bandung: CV. Sinar Baru.

Rita. 1996. Pengantar Psikologi. Jakarta: Erlangga.

Rosidi, Ajib. 1983. Pembinaan Minat Baca Bahasa dan Sastra. Bina Ilmu. Surabaya.

Soedarso. 1989. Sistem Membaca Cepat dan Efektif. Jakarta: PT. Gramedia.

Sudjana. 1989. Metoda Statistika. Bandung: Tarsito. 
Sugono, Dendy. 2003. Buku Praktis Bahasa Indonesia Jilid 2. Jakarta: Pusat Bahasa Departemen Pendidikan Nasional.

Suhendar, ME. dan Pien Supinah. 1992. Pengajaran dan Ujian Keterampilan Membaca dan Keterampilan Menulis. Bandung: Pionir Jaya.

Sukardi, Dewa Ketut. 1987. Bimbingan Perkembangan Jiwa Anak. Jakarta: Ghalia Indonesia.

Tampulonon, DP. 1987. Kemampuan Membaca Teknik Membaca Efektif dan Efisien. Bandung: Angkasa.

Tarigan, Henry Guntur. 1979. Membaca Sebagai Suatu Keterampilan Berbahasa. Bandung: Angkasa.

Walija. 1996. Komposisi Mengolah Gagasan Menjadi Karangan. Jakarta: Penebar Aksara. 
Jurnal Lentera Sains (Lensa)

34 Jurnal Lensa, Volume 5 Jilid I Mei 2015 